\title{
THE ARTHRITIS OF WHIPPLE'S SYNDROME
}

\author{
BY \\ D. E. CAUGHEY AND E. G. L. BYWATERS \\ M.R.C. Rheumatism Research Unit, Canadian Red Cross Memorial Hospital, Taplow, Maidenhead, Berks.
}

Since the original description by Whipple (1907) of a syndrome characterized clinically by "gradual loss of weight and strength, the stools consisting chiefly of neutral fat and fatty acids, indefinite abdominal signs and a peculiar multiple arthritis", arthralgia and arthritis have been noted to occur not infrequently in this condition. Although there have been a number of reviews of the syndrome, particularly in recent years (Farnan, 1959; Gross, Wollaeger, Sauer, Huizenger, Dahlin, and Power, 1959; Chears, Hargrove, Verner, Smith, and Ruffin, 1961) most of these have emphasized the gastro-intestinal manifestations. The purpose of this report is to describe the associated arthritis in greater detail.

\section{Case Report}

A 64-year-old widow was admitted to the Canadian Red Cross Memorial Hospital with arthritis, weakness, loss of weight, and pigmentation.

Joint symptoms had begun at the age of 25 years with bouts of aching and stiffness of the neck lasting for 2 to 3 weeks and recurring intermittently over the next 3 years. At age 30 the third metacarpophalangeal joints of each hand became swollen, red, stiff, and painful. The bouts of arthritis involving these joints lasted 2 to 3 weeks with intervals of freedom from symptoms lasting 2 to 3 months. Treatment with wax baths and gold injections was given. The attacks ceased after about 3 years, and for the next 24 years there were no joint symptoms. At age 57, however, the third and fourth metacarpophalangeal joints, ankles, knees, shoulders, and elbows became painful and swollen at intervals. One or more joints were affected at any one time and the skin over the joint was often hot and red. Each joint was involved for a minimum of several days and usually for 3 or 4 weeks, after which it would return to normal without residual change in appearance or function. The arthritis was not severe enough to interfere with the patient's household duties or her work in a factory.
In 1957 she was referred to a local hospital with loss of weight and arthritis. At this time the blood pressure was recorded as $210 / 140$, the erythrocyte sedimentation rate (E.S.R.) was $33 \mathrm{~mm}$./ $\mathrm{hr}$ (Westergren), and the haemoglobin 83 per cent. A provisional diagnosis of rheumatoid arthritis was made and during the next 2 years two courses of myocrisin (gold salts) were given. The joint pathology steadily improved, weight increased, the E.S.R. fell to $20 \mathrm{~mm}$./hr, and the patient was discharged from the out-patients' department. She then remained well with minimal trouble from arthritis until 6 months before admission, when she began to suffer from weakness and intermittent painful swellings of the knees, wrists, and right ankle. She was admitted to Maidenhead Hospital in October, 1961. A cervical lymph node biopsy showed reactive hyperplasia. The haemoglobin was 52 per cent. After a transfusion of blood she was transferred to the Canadian Red Cross memorial Hospital for further investigation.

Examination.-The patient showed wasting and pigmentation, the latter most marked over friction areas, scars, and about the vulvae; the mouth was spared. Ecchymoses were present over both ankles. Enlarged mobile non-tender discrete glands were palpable in the neck, axillae, and groins. The heart, chest, abdomen and central nervous systems showed no abnormalities. The blood pressure was $130 / 80$.

There was swelling and limitation of movement in the left shoulder, limitation of extension of the elbows and of flexion of the left hip and right knee. Movement of the thoracic and lumbar spine was impaired.

Laboratory Investigations: E.S.R. $93 \mathrm{~mm}$./ $\mathrm{hr}$ (Westergren); Hb 64 per cent. with anisochromia and normocytosis; white blood cell count 6,300 per c.mm. with a normal differential count. Differential sheep cell agglutination titre $1: 1$. Latex-fixation test negative.

Radiological Examination: Chest and knees normal. The hands showed general bone thinning and the feet bilateral hallux valgus with osteophytic lipping of the right first metatarsophalangeal joint.

From the left shoulder $5 \mathrm{ml}$. sterile, yellow, translucent fluid was aspirated, containing $4 \cdot 7$ g. per cent. protein. The bone marrow was poorly cellular and showed 
profound depression of erythropoeisis, normal myeloid series, a relative increase in lymphocytes, and no megaloblasts.

Progress.-The patient became weaker and more anaemic and continued to lose weight. The liver and spleen became easily palpable and the general lymphadenopathy more prominent. There was a further episode of acute arthritis with swelling, pain, and limited movement of the right wrist (Fig. 1) lasting 4 days. The diagnoses entertained at this stage were those of Addison's disease and malabsorption syndrome. That of Whipple's disease was mentioned.

A waterload test showed a delayed excretion, correctable with cortisone. As marked improvement and a rise in blood pressure followed the administration of cortisone for this test, cortisone was continued at $37 \cdot 5$ mg. daily. Subsequently the demonstration of a normal rise in plasma cortisol to $78 \mathrm{mg} . / 100 \mathrm{ml}$. after stimulation with ACTH showed the function of the adrenal cortex to be normal.

Despite the absence of bowel symptoms, malabsorption was reconsidered. The faecal fat excretion averaged $9 \mathrm{~g}$. daily on a diet of 70-80 g. fat and the glucose toler- ance curve was flat. The total serum proteins were 5.7 g. $/ 100 \mathrm{ml}$. with a reduced albumin peak. Serum iron was $15 \mu \mathrm{g} . / 100 \mathrm{ml}$., serum folic acid (L-casei assay) $4.6 \mathrm{~m} . \mu \mathrm{g} . / \mathrm{ml}$. (normal $6-22 \mathrm{~m} . \mu \mathrm{g} . / \mathrm{ml}$ ), and serum $\mathbf{B}_{12}$ level $240 \mu \mu \mathrm{g} . / \mathrm{ml}$. (normal 140-900 $\mu \mu \mathrm{g}$. $/ \mathrm{ml}$.).

The serum calcium, phosphorus, sodium, and potassium levels were normal.

Because of the slightly decreased fat absorption, low serum folic acid level, and flat glucose tolerance test, peroral jejunal biopsy was performed at Hammersmith Hospital under the care of Dr. C. C. Booth. The dissecting microscope appearances were of large bulbous villi with some ridging in places. Microscopically (Fig. 5A, below, p. 332) the jejunal villi were distended by large foamy macrophages containing granules which stained with periodic acid-Schiff (P.A.S.); these cells extended throughout the mucosa and a few extended into the muscle coat; many villi contained grossly dilated lymph channels. A firm diagnosis of Whipple's syndrome was made from these appearances. A re-examination of the lymph node biopsied earlier showed many small clusters of large histiocytes (Fig. 6, below, p. 333) containing P.A.S.-positive granules.

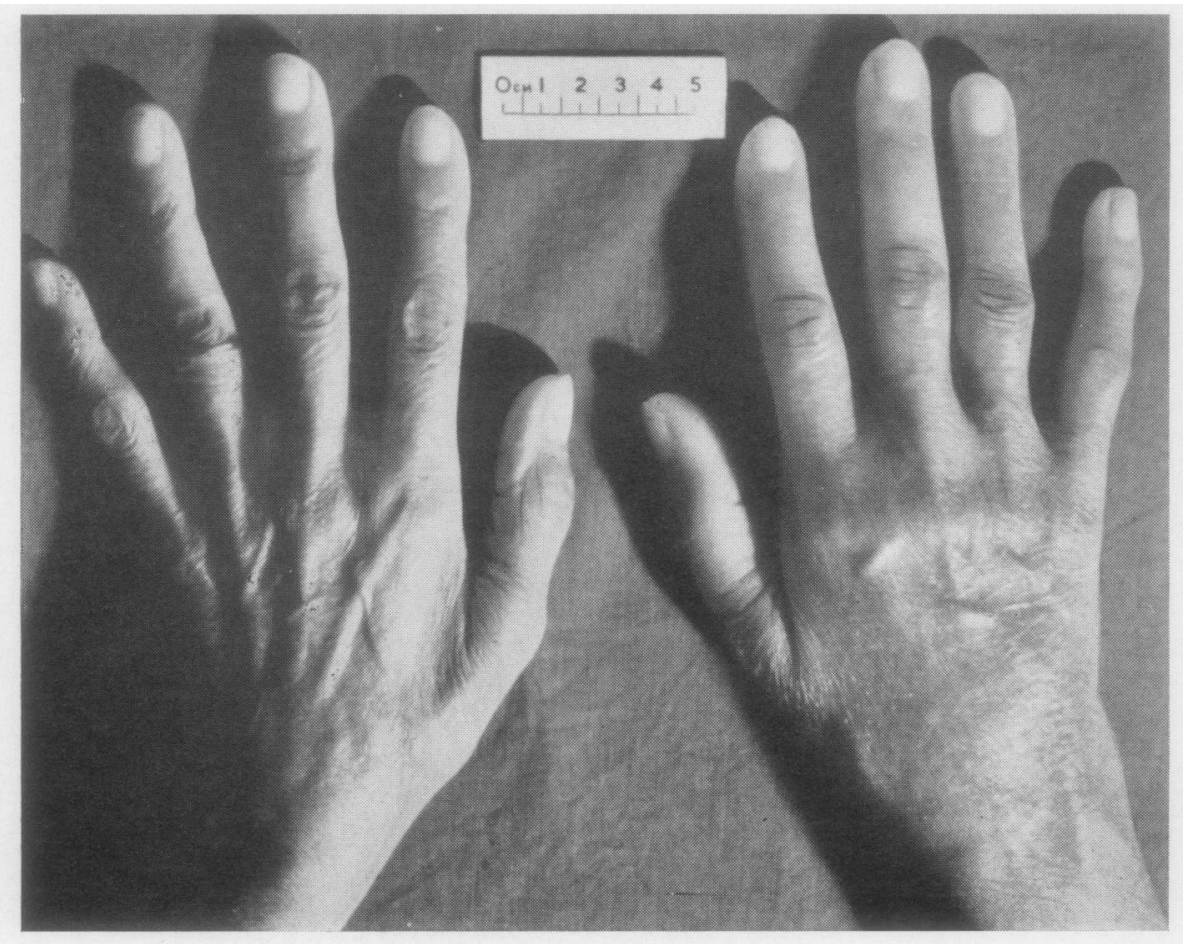

Fig. 1.-Swelling over dorsum of right wrist. 
The patient was discharged on January 1, 1962, on steroid therapy to be readmitted to the Hammersmith Hospital 6 weeks later for full metabolic studies. During this intervening period she lost further weight (Fig. 2) and remained markedly pigmented.

Generalized lymphadenopathy persisted, the blood pressure was now $90 / 60$, and there was slight pitting oedema over the sacrum. The erythrocyte sedimentation rate was $96 \mathrm{~mm}$./hr (Westergren), Hb 60 per cent. with anisocytosis. Platelets were plentiful. The white blood count was 6,000 per c.mm. and the sternal marrow showed normal iron stores but profound depression of erythropoiesis. The serum albumin was $1.9 \mathrm{~g}$. per cent. and the globulin $3 \cdot 2 \mathrm{~g} . / 100 \mathrm{ml}$. The blood urea was $52 \mathrm{mg}$./ $100 \mathrm{ml}$. The serum calcium, phosphate, alkaline phosphatase, sodium, and potassium levels were normal, and the serum cholesterol $95 \mathrm{mg} . / 100 \mathrm{ml}$. Occult blood was present in the stools on nine out of eleven occasions. The 24-hour faecal fat excretion was $14.8 \mathrm{~g}$. and $9.6 \mathrm{~g}$. on a $70 \mathrm{~g}$. fat diet (two 3-day collections). Xylose absorption was impaired (1.4 g. excreted in 5 hours after a $25 \mathrm{~g}$. oral dose (normal 5-8 g.)), and the folic acid absorption was low. The serum $B_{12}$ was $200 \mu \mu \mathrm{g}$./ ml., and $\mathbf{B}_{12}$ absorption was normal.

Radiological examination showed a probable ulcer on the lesser curve of the stomach and a duodenal pattern suggestive of extrinsic pressure from glands.

Synovial membrane from the right wrist (Fig. 3, overleaf) obtained by open biopsy showed a mild nonspecific synovitis with slight hyperplasia of the synovial lining, some increase in vascularity in the subendothelial tissue, and cuffing of small vessels by a few lymphocytes.
There were small deposits of haemosiderin. Some P.A.S positive staining granules were present in some cells but no more than in sections of rheumatoid arthritis synovia. Plasma cells were inconspicuous.

Towards the end of the third week there was an insidious but progressive deterioration in the patient's state without localizing signs. The blood pressure fell to 75/55 with episodes of flushing and Cheyne-Stokes respiration. 2 pints of blood and $200 \mathrm{mg}$. hydrocortisone were followed by cortisone $50 \mathrm{mg}$. 6-hrly. Antibiotic treatment started the following day (demethylchlortetracycline $150 \mathrm{mg}$. 6-hrly) with a further 2 pints of blood led to slow recovery and a rise in the blood pressure to $115 / 80$. Treatment with dimethyl-chlortetracycline was continued and the cortisone was reduced to $62.5 \mathrm{mg}$. daily.

The E.S.R. fell to $27 \mathrm{~mm} . / \mathrm{hr}$ (Westergren); the serum albumin rose to $3.1 \mathrm{~g} . / 100 \mathrm{ml}$., serum cholesterol to $185 \mathrm{mg}$. $/ 100 \mathrm{ml}$., Hb to 80 per cent. and the $24-\mathrm{hr}$ faecal fat excretion fell to normal ( 3.8 and $1.9 \mathrm{~g}$.).

The patient was discharged on cortisone $62.5 \mathrm{~ms}$. daily, demethyl chlortetracycline, ferrous sulphate, and Aludrox.

After discharge the patient gained weight and had no further diarrhoea or dizziness but complained of being easily fatigued. The glands became small, the spleen remained just palpable, and slight ankle oedema persisted. Cortisone was slowly reduced and the antibiotic was stopped after 6 weeks.

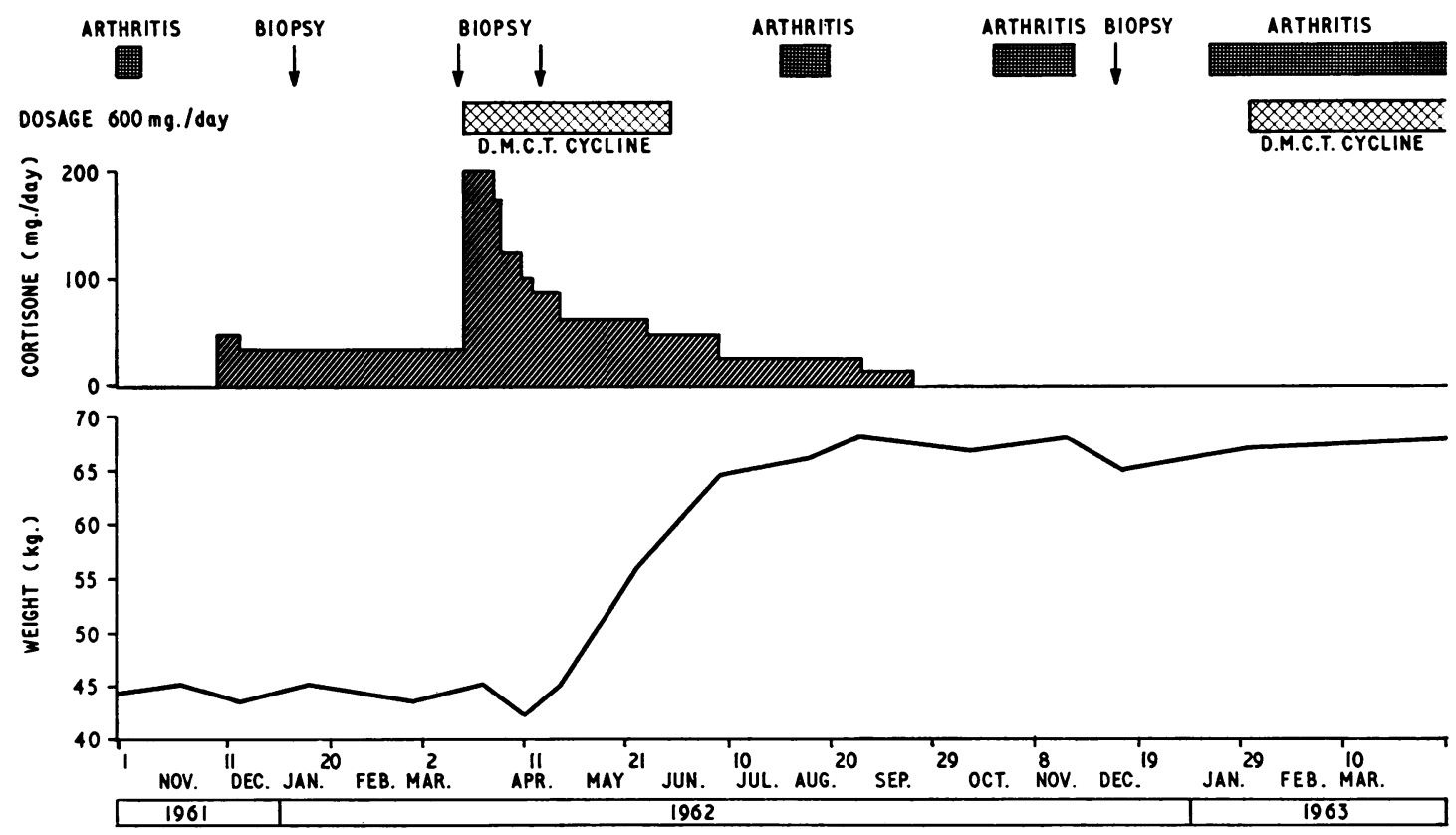

Fig. 2.-Treatment given during an 18-month period, changes in weight, intermittent arthritis, and times of jejunal biopsy. 


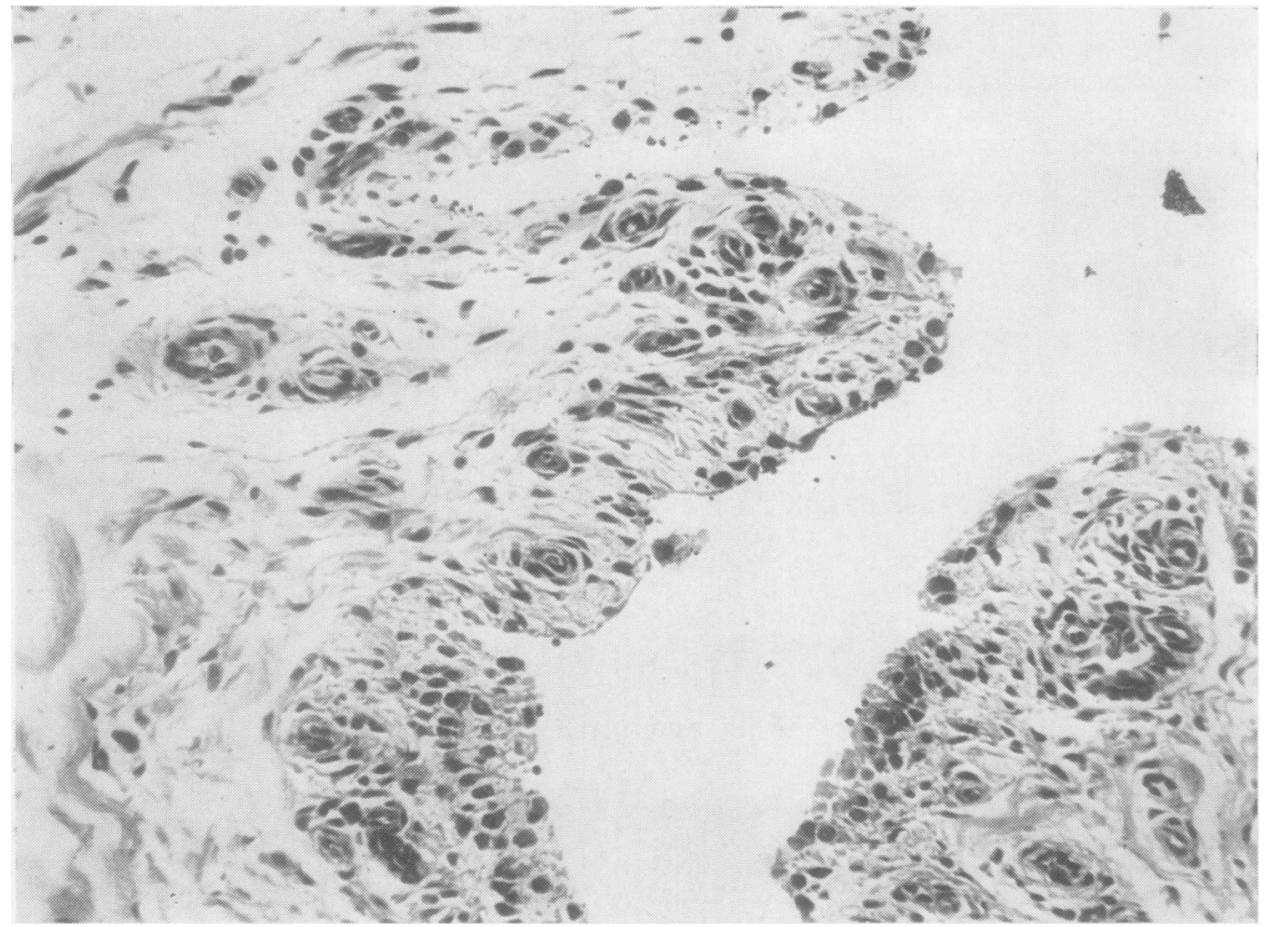

Fig. 3.-Synovium from right wrist, showing mild hyperplasia, some increase in vascularity in subendothelial tissues, and perivascular cuffing with lymphocytes. Haematoxylin and eosin. $\times 175$.

3 months after dischar $e^{e}$ the knees and left ankle again became stiff, swollen, and painful so that she had to remain in bed.

Readmission (August, 1962).--Only the left knee was painful, although both knees contained effusions. The left ankle was swollen with soft tissue thickening. The shoulders, hands, and wrists were now normal. There was no postural hypotension but pigmentation had increased. Axillary lymph glands were enlarged but examination of the abdomen was normal.

Aspiration of the left knee produced $12 \mathrm{ml}$. viscid yellow fluid containing $3.0 \mathrm{~g}$. per cent. protein (Table, p. 334) and $140 \mathrm{mg}$. per cent. glucose. A type I acetic acid clot was formed, and the viscosity relative to water at $37^{\circ} \mathrm{C}$. was 101. The differential agglutination titre of the fluid was $1: 2$ and the latex test was negative. The total white cell count of the fluid was 6,000 per c.mm. and a differential count showed polymorphs 30 per cent., lymphocytes 17 per cent., macrophages 48 per cent., synovial cells 4 per cent., and plasma cells 1 per cent. P.A.S. staining of the cells was negative (Fig. 4, opposite) and culture of the fluid was sterile. Needle biopsy revealed mild synovial hyperplasia with minimal infiltration of inflammatory cells as had been previously seen in the synovium from the wrist (Fig. 3).

6 weeks after discharge cortisone was finally stopped. The E.S.R. remained normal. A month later (October
$12,1962)$ the patient complained of increasing breathlessness but there were no abnormal signs in the chest. At times the wrists and elbows had been painful, and the knees and the third right proximal interphalangeal joint were found to be swollen, painful, and limited.

In November, 1962, the patient was readmitted to hospital. Pigmentation and bruising were again obvious and the axillary glands were easily felt. The abdomen was tumid but no masses were palpable. A trace of sacral oedema was present. The wrists were painful with limited movement, and the left was swollen with an effusion over the ulnar styloid. The knees were painful and contained fluid but had a full range of movement. The right knee was warm. Both ankles were swollen and limited, the left being warm and painful. The right second and third and left first and fourth metatarsophalangeal joints were tender but not thickened. The liver became enlarged.

A further jejunal biopsy (Dr. C. C. Booth) again showed patchy evidence of villous clubbing and macrophage invasion, but there was an overall improvement grossly and microscopically with decreased packing of macrophages and less P.A.S. staining (Fig. 5B, overleaf).

Demethyl-chlortetracycline was started without other therapy.

For the past 2 months the patient has been well but still complains of painful knees and postural giddiness. 




Fig. 4.-Cells from synovial fluid of knee, showing large vacuolated macrophages. Leishman. $\times 1,250$.

Pigmentation is still prominent but there is no lymphadenopathy and the abdomen is normal. When she was last seen in May, 1963, the wrists were painful on full dorsiflexion, there was swelling of the second and third left metacarpophalangeal joints, the ankles were slightly swollen, with pain on movement, and the metatarsophalangeal joints were tender.

Blood pressure 140/105; Hb 111 per cent.; E.S.R. $4 \mathrm{~mm}$./hr (Westergren); serum proteins $8 \cdot 1 \mathrm{~g}$. per cent., with a normal albumin peak on the electrophoretic strip.

It is proposed to continue the antibiotic for at least another 4 months.

\section{Discussion}

The diagnosis of Whipple's syndrome was made on jejunal biopsy when clubbed intestinal villi with characteristic histology were seen. Although considered initially, its occurrence in a woman is unusual (18 per cent. of published cases reviewed by Farnan, 1959). The more obvious features of weight loss, asthenia, anaemia, and widespread lymphadenopathy suggested a neoplastic condition such as a reticulosis or leukaemia, while the pigmentation and hypotension suggested Addison's disease. Bone marrow examination, however, was normal and the cervical lymph node showed normal architecture with reactive hyperplasia and no evidence of a neoplastic process; it was noted that there were occasional histiocytes scattered through the section and that some were grouped in clusters near the cortex of the gland (Fig. 6, overleaf). Many of these cells contained granules which stained positively with periodic acid-Schiff. These features have been described (Puite and Tesluk, 1955) as sufficiently characteristic for a diagnosis of Whipple's syndrome and have been described in lymph nodes away from the main intestinal drainage path. In our experience, although, in rheumatoid arthritis, there are occasional histiocytes scattered through the lymph node and some contain small P.A.S.positive granules, such clusters of macrophages containing fairly large amounts of P.A.S.-positive granules, are not seen in the reactive hyperplasia characteristic of rheumatoid arthritis. Such dissemination of P.A.S.-positive particles is known to occur widely in the body and may quite often be seen in the endocardium and in peripheral lymph nodes (Rutishauser and Borer, 1959).

The presentation of the condition as an Addisonian-like state is well described (Glynn 




(A)

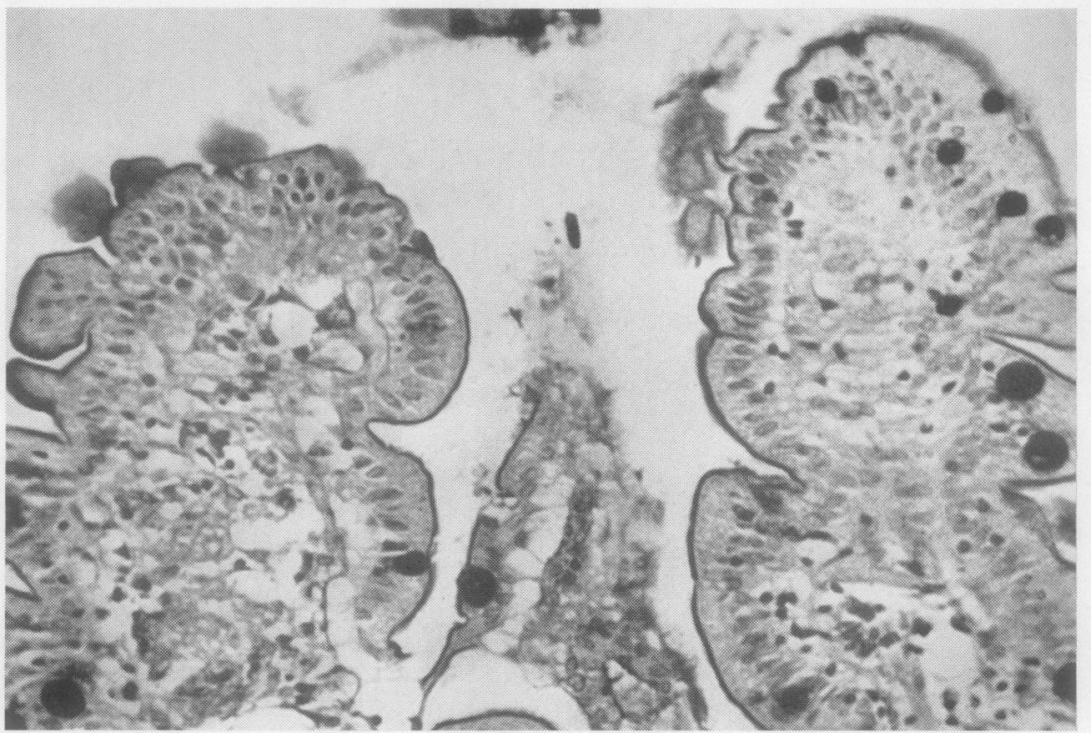

(B)

Fig. 5.-(A) Original jejunal biopsy, showing clubbed villus full of large macrophages containing P.A.S.-positive granules. P.A.S. $\times 188$ (B) Jejunal biopsy 11 months later, showing reduction in number of macrophages and P.A.S.-positive granules. P.A.S. $\quad \times 188$.

and Rosenheim, 1938; Gross and others, 1949; Jones and Paulley, 1949), and Gross and others (1959) reported the excretion of a water load to be abnormal. The latter was delayed in this case and correctable with cortisone despite normal plasma cortisol levels and in the absence of gross steatorrhoea. There were no abdominal symptoms and no complaint of diarrhoea until after the first hospital admission. The stools were macroscopically normal and not until the flat glucose tolerance test and low serum folic acid levels were returned was the faecal fat excretion estimated and found to be raised. The occurrence of peptic ulceration is not infrequent in the reported cases. 




Fig. 6. - Cervical lymph node, showing cluster of macrophages with foamy cytoplasm which stained positively with P.A.S. $\quad \times 208$.

Despite the history of a reasonably symmetrical inflammatory polyarthritis, the absence of residua after so long a time, the normal radiographs and negative serology made the diagnosis of rheumatoid arthritis untenable. Apart from the original description, the pattern of the arthritis has been poorly documented. Many authors have described arthralgia or arthritis in association with this condition and of sixty cases collected by Farnan (1959), 41 had arthritis. Myalgia is occasionally mentioned as a symptom (Gross and others, 1959). The joint symptoms may precede other symptoms by 13 to 18 years (Pemberton, Comfort, Fair, and Zaslow, 1947; Jarcho, 1936). Several cases have been described in which the arthritis remitted with the onset of gastro-intestinal symptoms, or with the final period of decline (Gross and others, 1959). Involvement of most joints has been described, those commonly affected being the ankles, knees, shoulders, and wrists; the smaller joints are less often the site of arthritis. Pain is usually slight but it may be severe. Stiffness is less often a feature, but migratory stiffness was the only complaint of one case recorded by Gross and others
(1959). The joints are often swollen, contain fluid and are limited in their movement. Occasionally the skin over the joint is red and hot. The arthritis may involve several joints within a period of one or two days. It may last hours, one or two days, or weeks, and then characteristically resolves completely leaving no residue. In one case a severe widespread recurrence of arthritis followed a wrist fracture. The patient may have several years between attacks of arthritis completely free of symptoms.

Various medications have been used, namely gold, steroids, salicylates, and antibiotics, but the response has been variable and no one treatment has brought constant relief. In this case arthritis recurred while on steroid and antibiotic therapy. Although a response to gold earlier in the course was said to have occurred on two occasions, this improvement may well have been due to a natural remission. Symptomatic pain relief is usually all that is required for joint symptoms, and paracetamol was used in this patient.

Joints have been described as macroscopically normal post mortem (Farnan, 1959; McDonald, 
1961, personal communication), or as resembling those of chronic arthritis (Jarcho, 1936), but synovial histology has not hitherto been described. The synovitis was in no way specific. Both in the wrist (Fig. 3) and in the knee there was mild synovial hyperplasia, increased vascularity, and some perivascular cuffing with lymphocytes. None of the characteristic P.A.S.-staining macrophages were demonstrable in the synovium. The only reference we have found in the literature is contained in a personal communication from Zollinger (cited by Rutishauser and Borer, 1959) that such cells were present in one case in the synovium. Electron microscopic appearances are to be reported separately (D. V. Davies and E. G. L. Bywaters).

The findings in the synovial fluid are shown in the Table. In three specimens the protein content varied between 3 and $4.7 \mathrm{~g}$. per cent. and the acetic acid clot was type $I$. The most striking feature was the high proportion of mononuclear cells and the relatively smaller proportion of polymorphonuclear cells. Of the mononuclears there were several clumps of large vacuolated cells (Fig. 3), some of which contained ingested material in their cytoplasm, and these were taken to be macrophages. They did not stain positively with P.A.S.

\section{TABLE}

COMPARISON OF THE SYNOVIAL FLUIDS TAKEN FROM THE RIGHT AND LEFT KNEES AT DIFFERENT TIMES

\begin{tabular}{|c|c|c|c|c|c|}
\hline \multirow{2}{*}{\multicolumn{4}{|c|}{ Synovial Fluid }} & \multicolumn{2}{|c|}{ Knee } \\
\hline & & & & \multirow{2}{*}{$\begin{array}{c}\begin{array}{c}\text { Left } \\
10.8 .62\end{array} \\
\begin{array}{c}\text { Yellow } \\
\text { translucent }\end{array}\end{array}$} & \multirow{2}{*}{\begin{tabular}{|c|} 
Right \\
9.2 .63 \\
$\begin{array}{c}\text { Yellow } \\
\text { translucent }\end{array}$
\end{tabular}} \\
\hline Colour & . & . & . & & \\
\hline \multicolumn{4}{|c|}{ Viscosity (relative to water $37^{\circ} \mathrm{C}$.) } & 101 & $20 \cdot 35$ \\
\hline \multicolumn{2}{|c|}{ Acetic Acid Clot } & .. & .. & Type I & Type I \\
\hline \multicolumn{3}{|c|}{ Protein (g. per cent.) } & . & $3 \cdot 0$ & $4 \cdot 1$ \\
\hline Culture & .. & .. & .. & No growth & No growth \\
\hline \multicolumn{2}{|c|}{$\begin{array}{c}\text { Total W.B.C. (per c } \\
\text { Polymorphs } \\
\text { Lymphocytes } \\
\text { Macrophages } \\
\text { Synovial cells } \\
\text { Plasma cells }\end{array}$} & $\begin{array}{l}\text { c.mm.) } \\
. \\
\ldots \\
\ldots \\
\ldots\end{array}$ & $\begin{array}{l}. \\
\because \\
\because \\
\therefore\end{array}$ & $\begin{array}{c}6,000 \\
30 \\
17 \\
48 \\
4 \\
1\end{array}$ & $\begin{array}{c}13,200 \\
45 \\
33 \\
14 \\
8 \\
0\end{array}$ \\
\hline
\end{tabular}

There is a similar paucity of observation on the radiographic appearance of the joints. Sailer and McGann (1942), Gross and others (1959), and Jones, Benson, and Roque (1953) have described changes as being compatible with rheumatoid arthritis. Eyler and Doub (1956) described two cases with sclerosis and other changes in the sacro-iliac joints. However, one of the cases previously reported (Puite and Tesluk, 1955) had had a gonococcal urethritis 5 years before, followed by orchitis and epididymitis.

Our patient showed radiologically only the changes of degenerative joint disease appropriate to her age and the sacro-iliac joints were radiologically normal. The sheep cell agglutination titre and latex tests were negative. Other published cases lack these data.

Many forms of treatment have been suggested. A recent evaluation by Davis, McBee, Borland, Kurtz, and Ruffin (1963) of steroids and antibiotics found five cases who did poorly or relapsed on steroids, and two of these recovered when given antibiotics. Of the cases treated with antibiotics (penicillin and streptomycin for 10 days and then tetracycline $1 \mathrm{~g}$. daily for 10-12 months), none had relapsed.

Our patient showed definite but temporary clinical improvement on cortisone alone. The relapse, leading to sudden peripheral circulatory failure, responded to increased steroid dosage and demethyl-chlortetracycline given for 6 weeks. The jejunal biopsy appearances 8 months later were improved. When the patient was finally weanect from steroid, a relapse occurred, but this is respond ing well to demethyl-chlortetracycline alone. Epi sodes of arthritis have occurred both on antibiotics and on steroids. They seem to be less frequent since antibiotics alone were restarted. They have caused little disability and have responded to symptomatic treatment. It is hoped that after the second course of demethyl-chlortetracycline over the next 6 months, a clinical and histological improvement will occur and be maintained. A spontaneous remission without treatment for as long as 4 years has been reported (Gross and others, 1959), but this is rare if judged by the prognosis of cases described before the advent of antibiotics and steroids.

\section{Summary}

A case is reported of Whipple's syndrome diagnosed by peroral jejunal biopsy, in which arthritis preceded other symptoms by 35 years. The pattern of the arthritis, the cytological changes in the synovial fluid, and the synovial histology of the biopsy specimens are described. Clinical improvement and changes in the jejunal biopsy occurred after treatment with demethyl-chlortetracycline.

We wish to thank Dr. G. T. Thomas, who originally saw and referred this patient, Dr. C. C. Booth of the 
Postgraduate Medical School, in whose department the metabolic studies and jejunal biopsies were performed, and Dr. D. L. Mollin of the M.R.C. Haematology Unit, Hammersmith Hospital, in whose department the haematological investigations were carried out. It is also a pleasure to acknowledge the help and advice of Dr. B. M. Ansell in the preparation of this paper.

\section{REFERENCES}

Chears, W. C., Jr., Hargrove, M. D., Jr., Verner, J. V., Jr., Smith, A. G., and Ruffin, J. M. (1961). Amer. J. Med., 30, 226.

Davis, T. D., Jr., McBee, J. W., Borland, J. L., Jr., Kurtz, S. M., and Ruffin, J. M. (1963). Gastroenterology, 44, 112.

Eyler, W. R., and Doub, H. P. (1956). J. Amer. med. Ass., 160, 534.

Farnan, P. (1959). Quart. J. Med., 28, 163.

Glynn, L. E., and Rosenheim, M. L. (1938). J. Path. Bact., 47, 285.

Gross, J. B., Wollaeger, E. E., Sauer, W. G., Huizenga, K. A., Dahlin, D. C., and Power, M. H. (1959). Gastroenterology, 36, 65.

Jaffe, I. A. (1961). Ann. intern. Med., 54, 776.

Jarcho, S. (1936). Bull. Johns Hopk. Hosp., 59, 275.

Jones, C. M., Benson, J. A., and Roque, A. L. (1953). New Engl. J. Med., 248, 665.

Jones, F. Avery, and Paulley, J. W. (1949). Lancet, $1,214$.

McDonald, W. I. (1961). N.Z. med. J., 59, 82.

Pemberton, J. deJ., Comfort, M. W., Fair, E., and Zaslow, J. (1947). Surg. Gynec. Obstet., 85, 85.
Puite, R. H., and Tesluk, H. (1955). Amer. J. Med., 19, 383.

Rutishauser, E., and Borer, F. (1959). Schweiz. med. Wschr., 89, 397.

Sailer, S., and McGann, R. J. (1942). Amer. J. dig. Dis., 9, 55.

Whipple, G. H. (1907). Bull. Johns Hopk. Hosp., 18, 382.

\section{L'arthrite du syndrome de Whipple}

\section{RÉSUMÉ}

On rapporte un cas de syndrome de Whipple, identifié par une biopsie jéjunale par voie buccale. L'arthrite y avait précédée les autres symptômes de 35 ans. On décrit le tableau arthritique, les altérations cytologiques dans le liquide synovial et l'histologie synoviale des prélèvements. Une amélioration clinique et des altérations des prélèvements jéjunaux ont été observés après le traitement par la démethyl-tetracycline.

\section{La artritis del sindrome de Whipple}

\section{Sumario}

Se relata un caso de síndrome de Whipple, reconocido por una biopsia yeyunal peroral, en que la artritis había precedido otros síntomas de 35 años. Se describen el cuadro artrítico, las alteraciones citológicas en el líquido sinovial y la histología sinovial de los cortes de biopsia. Una mejoría clínica y alteraciones de los cortes yeyunales fueron observadas después del tratamiento con la demetil-tetraciclina. 